\title{
VIRAL MARKETING MESSAGE, CONSUMERS’'ATTITUDE TOWARDS VIRAL MARKETING, COMPETITIVENESS ABILITY, AND BUSINESS PERFORMANCE
}

\author{
Trixie Nova Bella Tandijaya ${ }^{1}$, Hatane Semuel ${ }^{*}$ \\ ${ }^{12}$ Faculty of Business and Economics, Petra Christian University, Surabaya \\ Email: 1d21200011@john.petra.ac.id; ${ }^{2}$ samy@petra.ac.id \\ * Penulis korespondensi
}

\begin{abstract}
Abstrak: Pemberdayaan teknologi dan pemanfaatan media digital yang saat ini dipraktikkan melalui strategi dan taktik pemasaran yang tepat akan mampu membuat bisnis tetap bertahan di tengah pandemi Covid-19. Strategi pemasaran viral adalah strategi pemasaran efektif berbiaya rendah untuk penargetan massal. Promosi viral yang kuat dapat menjangkau ribuan konsumen, dapat menginspirasi mereka untuk membeli produk bermerek tertentu, dan menciptakan keunggulan kompetitif bagi bisnis. Penelitian ini mengambil UKM Kerajinan Kulit Tanggulangin sebagai salah satu sentra industri kulit di Indonesia, dengan variabel penelitian adalah viral marketing message strategies, consumer attitudes towards viral marketing, competitiveness ability, dan business performance. Penelitian dilakukan terhadap 235 responden yang memenuhi persyaratan ketentuan penelitian. Analisis data menggunakan SmartPLS 3. Hasil yang diperoleh adalah viral marketing massage berpengaruh langsung positif terhadap consumer attitudes towards viral marketing, competitiveness ability, dan business performance. Consumer attitudes towards viral marketing memiliki pengaruh positif langsung competitiveness ability, dan business performance. Selain itu, consumer attitudes towards viral marketing memediasi parsial hubungan antara viral marketing massage dan competitiveness ability, dan competitiveness ability memediasi parsial hubungan antara consumer attitudes towards viral marketing dan business performance.
\end{abstract}

Kata kunci: Online marketing communication, viral marketing message, consumers' attitude toward viral marketing, competitiveness ability, business performance

\begin{abstract}
Empowerment of technology and the use of digital media that are currently practiced through appropriate marketing strategies and tactics will be able to make businesses survive in the midst of the Covid-19 pandemic. Viral marketing strategy is a low-cost effective marketing strategy for mass targeting. Powerful viral promotions can reach thousands of consumers, can inspire them to buy certain branded products, and create a competitive advantage for businesses. This study takes the Tanggulangin leather craft SMEs as one of the centers of the leather industry in Indonesia, with the research variables being viral marketing message strategies, consumer attitudes towards viral marketing, competitiveness ability, and business performance. The study was conducted on 235 respondents who met the requirements of the research provisions. Data analysis using SmartPLS 3. The results obtained are that viral marketing massage has a direct positive effect on consumer attitudes towards viral marketing, competitiveness, and business performance. Consumer attitudes towards viral marketing have a direct positive effect on competitiveness and business performance. In addition, consumer attitudes towards viral marketing partially mediate the relationship between viral marketing messages and competitiveness, and competitive ability partially mediates the relationship between consumer attitudes towards viral marketing and business performance.
\end{abstract}

Keywords: Online marketing communication, viral marketing message, consumers' attitude toward viral marketing, competitiveness ability, business performance.

\section{PENDAHULUAN}

Pandemi Covid-19 di Indonesia membawa dampak ke berbagai sektor ekonomi termasuk industri kerajinan kulit, salah satunya adalah UKM Kerajinan Kulit Tanggulangin, Sidoarjo. Meskipun demikian, menurut Kementerian Perindustrian, nilai ekspor produk kulit alas kaki dan barang jadi kulit dari Indonesia, berada pada posisi keenam di dunia dan mencapai US\$ 4,16 miliar pada Januari-September 2018, meningkat 6,28\% dari periode yang sama tahun 2017 (Bella, 2018). UKM perlu menyesuaikan diri di kala pandemi ini sehingga pertumbuhan industri kerajinan kulit dapat tetap memberikan kontribusi pada perekonomian Indonesia dimasa depan, terutama dari potensi besar pada bidang e-commerce. Agung Bayu Purwoko, Principal Economist Payment System Policy Department Bank Indonesia mengatakan bahwa nilai transaksi e-commerce meningkat karena mobile customer mencapai 338,2 juta, pengguna internet 175,4 juta orang, dan pengguna aktif media sosial 160 juta orang (Antara \& Setiawan, 2020). Data Bank Indonesia menyebut transaksi e-commerce naik dari 40 juta transaksi (2018) menjadi 80 juta transaksi (2019) hingga mencapai angka 140 juta di tahun 2020. Pertumbuhan tersebut perlu dimanfaatkan oleh pelaku 
UKM dalam mengkomunikasikan produk secara intensif dengan melakukan pemasaran produk menggunakan digital marketing. Menurut Teten Masduki, Menteri Koperasi dan Usaha Kecil dan Menengah (UKM), saat ini baru sekitar $13 \%$ atau 8 juta UKM yang masuk ke ekosistem digital (Antara \& Setiawan, 2020). Optimalisasi digital dapat menjadi langkah untuk memastikan roda ekonomi tetap berputar, karena UKM produktif kunci pemulihan ekonomi. Hal ini didukung oleh Agus Suparmanto, Menteri Perdagangan, mengemukakan bahwa penting bagi UKM untuk masuk ke platform digital (Antara \& Setiawan, 2020).

Berdasarkan data yang dikumpulkan oleh peneliti melalui wawancara dengan Anggota Komisi B DPRD Jawa Timur, para pemilik UKM Kerajinan Kulit Tanggulangin, Sidoarjo termasuk di dalam wadah besar industri aneka, yang total jumlah jenis bisnisnya mencapai 225 macam dengan jumlah tenaga kerjanya mencapai 74.455 orang (Rohi; wawancara 15 Maret '21). Dari data tersebut, dapat dilihat bahwa UKM Kerajinan Kulit Tanggulangin memiliki potensi yang cukup besar untuk membantu pemulihan ekonomi negara pasca pandemi. Perkembangan teknologi dan media digital memungkinkan terjadinya pertumbuhan bisnis yang pesat tanpa memandang skalanya, salah satunya adalah melalui strategi pesan pemasaran viral. Salah satu contoh nyata terlihat pada fenomena "odading" yang mendadak viral sejak video penjualnya bernama Mang Sholeh (Oleh) melakukan promosi dengan kata-kata kasar dan nyeleneh ditambah nada ngegas (Bramasta, 2020). Kudapan khas Bandung tersebut semakin ramai diperbincangkan setelah video review kuliner yang dibuat artis Instagram Ade Londok viral di media sosial (Travel, 2020).

Untuk itu perusahaan atau pemilik usaha harus menggeser penggunaan media pemasaran konvensional (offline) ke media pemasaran online (Castronovo $\&$ Huang, 2012) untuk menciptakan pesan pemasaran yang viral. Viral marketing merupakan strategi pemasaran yang efektif dengan biaya rendah untuk penargetan massal (Putri \& Ernawaty, 2019), bebas dari batasan geografis dan batasan waktu, yang memiliki potensi jangkauan global dibandingkan dengan komunikasi konvensional (Goldsmith \& Horowitz, 2006). Viral marketing yang diinduksi Internet adalah alat yang efektif untuk digunakan oleh pemasar saat ini (Jensen, 2008). Pesan pemasaran yang kuat dapat menjangkau ribuan konsumen dan dapat menginspirasi mereka untuk membeli suatu merek (Bampo et al., 2008) sehingga dapat menciptakan keunggulan kompetitif bagi bisnis. Kriteria ini sangat penting dalam mencapai keunggulan kompetitif melalui viral message. Keunggulan kompetitif dapat dicapai dengan dua cara berbeda: menciptakan kepemimpinan biaya dan menciptakan diferensiasi (Porter, 1985). Ini adalah elemen kunci dari perusahaan yang digunakan untuk mengukur dan membedakan perusahaan dari pesaingnya (Tracey et al., 1999). Perusahaan yang memiliki keunggulan kompetitif baik dari diferensiasi atau biaya, dapat menciptakan dan meningkatkan kinerja finansial maupun kinerja merek yang lebih baik di perusahaan (Ma, 2000).

Literatur terkait viral marketing mencatat bahwa sebagian besar riset hanya berfokus pada pesan dan dampak nya terhadap sikap dan perilaku konsumen. Zernigah dan Sohail (2012) menemukan bahwa konsumen Pakistan memiliki sikap yang positif terhadap pesan pemasaran viral. Cruz dan Fill (2008) meneliti efektivitas kampanye viral marketing pada beberapa web master terkemuka yang memimpin pengembangan banyak aktivitas viral marketing di Inggris Raya. Selain itu, Putri dan Ernawaty (2019) juga melakukan penelitian yang bertujuan untuk mengetahui konten viral marketing yang tepat untuk kampanye Universal Health Coverage di Indonesia. Dua variabel utama yang menjadi perhatian para peneliti sebelumnya adalah Viral Marketing Messsage (VM) dan Consumers' Attitude Towards Viral Marketing (CATVM) namun belum mengikutsertakan dampaknya terhadap kinerja bisnis seperti keunggulan kompetitif (contoh: Competitiveness AbilityCA) atau kinerja bisnis (contoh: Business Performance-BP). Selain itu, literatur Viral Marketing juga belum memberikan kerangka konseptual maupun praktis yang dapat mengukur secara simultan hubungan keempat variabel yang disebutkan diatas. Pada penelitian ini, penulis mencoba memberikan model konseptual yang mengukur hubungan antara VM, CATVM, CA, dan BP dalam sebuah model yang mengintegrasikan empat teori utama yaitu Theory of Planned Behavior (TBP), Technology Acceptance Model (TAM), Technology Organization Environmental (TOE) dan Diffusion of Innovation (DOI). Kerangka tersebut di analisa melalui desain riset perilaku konsumen UKM UKM Kerajinan Kulit Tanggulangin, Sidoarjo dengan tujuan untuk memberikan bukti empiris dampak strategi pemasaran viral terhadap keunggulan bersaing maupun kinerja bisnis nya.

\section{LANDASAN TEORI}

\section{Technology \& Marketing}

Multiplikasi dampak upaya pemasaran sebuah bisnis dapat dilakukan melalui kombinasi teknologi dan strategi dan taktik pemasaran konvensional. Untuk menjembatani hal tersebut, penulis merujuk pada 
empat teori utama yang menjadi dasar penentuan variabel-variabel penelitian. Theory of Planned Behavior (TBP) diperkenalkan oleh Ajzen (1987) telah diterapkan dan divalidasi secara langsung atau tidak langsung oleh studi sebelumnya terkait consumer adoption terhadap e-commerce dan mobile advertising (Bauer et al., 2005; Lee et al., 2006; Pavlou \& Fygenson, 2006; Shen \& Chen, 2008; Tsang et al., 2004; Zhang, 2010). Konsep TPB diadopsi untuk menganalisa CATVM dimana niat konsumen untuk melakukan berbagai jenis perilaku dapat diprediksi dengan akurasi tinggi dari attitude toward behaviour, subjective norms dan perceived behavioral control (Icek, 1991). Untuk menganalisa niat individu dalam mengadopsi dan menggunakan teknologi informasi baru, teori Technology Acceptance Model (TAM) menjadi rujukan dengan berfokus pada perceived usefulness (PU) dan perceived ease of use (EOU). Menurut Davis (1989), perceived usefulness merupakan tingkat kepercayaan seseorang bahwa menggunakan suatu teknologi tertentu akan meningkatkan kinerja mereka sedangkan perceived ease of use merujuk pada tingkat kepercayaan seseorang bahwa teknologi informasi dapat dengan mudah dipahami. Penelitian yang dilakukan oleh Yang \& Zhou (2011) pada konsumen muda Amerika menemukan bahwa perceived ease of use berpengaruh positif dengan niat konsumen untuk meneruskan viral content dan juga membuktikan bahwa TAM cocok untuk mobile viral marketing karena perceived utility dari viral message dengan kuat berpengaruh pada niat konsumen untuk meneruskan pesan elektronik yang entertaining dan useful. Level adopsi teknologi dalam upaya pemasaran sebuah bisnis perlu diukur juga dampaknya terutama pada keunggulan kompetitif dan kinerja bisnis tersebut.

Tornatzky, Fleischer dan Chakrabarti (1990) merujuk pada teori Technology Organization Environmental (TOE) untuk meneliti bagaimana keputusan untuk mengadopsi inovasi teknologi didasarkan pada faktor-faktor dalam konteks organisasi dan lingkungan, serta karakteristik teknologi itu sendiri. Hal-hal yang perlu diperhatikan perusahaan adalah ukuran perusahaan, derajat sentralisasi, formalisasi, kompleksitas struktur manajerial, kualitas sumber daya manusianya, dan jumlah sumber daya kendur yang tersedia secara internal (Chau \& Tam, 1997). Teori Diffusion of Innovation (DOI) memperjelas hubungan antara keputusan adopsi inovasi teknologi dengan kapasitas perusahaan dengan memberikan prediksi dampak nya pada atribut-atribut relative advantage, compatibility, complexity, trialability, and observability (Ahmad et al., 2019). Relative advantage adalah sejauh mana inovasi dapat membawa manfaat bagi organisasi.
Compatibility adalah sejauh mana suatu inovasi konsisten dengan proses bisnis, kebiasaan, dan sistem nilai yang ada. Complexity adalah sejauh mana inovasi sulit digunakan. Observability adalah sejauh mana hasil inovasi terlihat oleh orang lain. Trialability adalah sejauh mana inovasi dapat diujicobakan.

Penelitian ini menggunakan kerangka kerja TOE yang dikombinasikan dengan beberapa karakteristik dari teori DOI untuk menyelidiki dampak adopsi media sosial terhadap kinerja UKM dari perspektif perilaku konsumen target berdasarkan teori TPB. Studi ini menggunakan dukungan pemilik/ manajemen media sosial UKM Kerajinan Kulit Tanggulangin, Sidoarjo sebagai proxy untuk konteks organisasi penuh.

\section{Online Marketing Communication}

Instrumen pemasaran menawarkan tiga strategi pemasaran dasar - push, pull, and viral strategies (Wiedemann, 2007). Dalam strategi push, pemasar mengarahkan konsumen untuk mendistribusikan produk dan/atau mengkomunikasikannya melalui konten di media sosial. Dalam strategi pull, pemasar menggunakan strategi persuasif dan memberikan stimulus-stimulus tertentu yang tidak secara langsung menjual kepada konsumen. Dalam strategi viral, pertukaran informasi terjadi di antara konsumen berdasarkan konten pemasaran tertentu (push maupun pull). Strategi yang terakhir termasuk dalam konsep viral marketing, dimana salah satu bentuknya adalah electronic word of-mouth (eWOM) (Wiedemann, 2007). Kemajuan teknologi komunikasi menjadi ladang terciptanya berbagai bentuk komunikasi viral marketing (Haryani \& Motwani, 2015). Meneruskan informasi ke sekelompok besar pengguna internet dapat menyebabkan penyebaran informasi secara luas (viral), yang sering dikenal sebagai eWOM (Meyliana et al., 2015). Viral marketing menjelaskan fenomena di mana konsumen secara bersama-sama berbagi dan menyebarkan secara eksponensial informasi yang diperoleh dari pemasar untuk merangsang dan memanfaatkan perilaku word-of-mouth (Van der Lans, van Bruggen, Eliashberg, \& Wierenga, 2010). EWOM bukan merupakan bagian dari iklan yang bersifat komersial karena disalurkan dari konsumen ke konsumen, bukan dari perusahaan ke konsumen. Pesan jenis ini memberikan pengalaman langsung kepada konsumen dan mempengaruhi keputusan konsumen lainnya (Godes \& Mayzlin, 2004; Park et al., 2007).

Media sosial juga dipandang sebagai alat yang menjadi wadah pesan berantai yang didistribusikan dari orang ke orang lain. Pesan berantai inilah yang menjadi tujuan dari aktivitas-aktivitas viral marketing sebagai bentuk promosi pemasaran. Kaplan dan 
Haenlein (2011) mengungkapkan bahwa faktor-faktor penentu dalam viral marketing adalah pembawa pesan, isi pesan, dan lingkungan. Ketiga faktor akan menghubungkan pesan tersebut kepada calon konsumen yang akan menggunakan barang atau jasa yang ditawarkan serta merekomendasikannya kepada konsumen lain.

\section{Viral Marketing Message}

Konsep viral menggambarkan jenis pemasaran yang mempersuasi pelanggan dengan sebuah pesan iklan yang memunculkan mata rantai aktivitas aktif dalam membagi pesan tersebut dari satu pelanggan ke pelanggan lainnya (Palka et al., 2009). VM merupakan strategi yang mendorong individu untuk menyampaikan pesan pemasaran kepada orang lain dan menciptakan potensi pertumbuhan dalam hal paparan serta pengaruh dari pesan tersebut (Pandey et al., 2012). Tujuan dari VM adalah untuk menggunakan consumer-to-consumer (or peer-to-peer) communication untuk menyebarkan informasi tentang suatu produk atau layanan, sehingga proses komunikasi menjadi lebih cepat (Krishnamurthy, 2001). Kaplan dan Haenlein (2011) mengungkapkan bahwa faktorfaktor penentu dalam VM adalah pembawa pesan, isi pesan, dan lingkungan. Penelitian ini mengadopsi konsep VM berdasarkan riset Zernigah dan Sohail (2012) yang berfokus pada tingkat probabilitas kecenderungan seseorang untuk bersedia menyebarkan pesan pemasaran viral ke jejaring sosial nya. Terdapat empat dimensi dalam $V M$ yang mempengaruhi sikap konsumen yaitu:

\section{Informativeness}

Iklan yang informatif tidak hanya membuat konsumen sadar akan produk baru, tetapi juga menginformasikan konsumen bahwa produk tersebut lebih baik dari yang ditawarkan pesaing (Saadeghvaziri \& Hosseini, 2011). Informativeness dapat dijelaskan melalui kemampuan pesan pemasaran untuk berbagi informasi dengan konsumen mengenai rentang produk yang berbeda untuk memaksimalkan kepuasan konsumen dan kemampuan untuk berhasil memberikan informasi terkait (Waldt et al., 2009). Zernigah dan Sohail (2012) memberikan tiga indikator dari informativeness yaitu informative (memberikan informasi yang relevan dengan kebutuhan penerimanya), useful (memberikan informasi yang berguna bagi penerimanya) dan important (memberikan informasi yang penting bagi penerimanya).

\section{Entertainment}

Entertainment diartikan sebagai kemampuan untuk memenuhi kebutuhan pemirsa akan kenikmatan visual, hiburan yang menyenangkan, atau kesenangan emosional (Ducoffe, 1996). Penting bagi konsumen untuk menikmati pesan-pesan pemasaran yang dikirimkan oleh pemasar dalam mengembangkan sikap terhadap viral marketing message. Dalam penelitian ini menggunakan indikator entertainment yang dikemukakan oleh Zernigah \& Sohail (2012), dimana empat indikator dari entertainment tersebut adalah entertaining (memberikan pesan yang menghibur bagi penerimanya), exciting (memberikan pesan yang seru bagi penerimanya) dan interesting (memberikan pesan yang menarik bagi penerimanya).

3. Source Credibility

MacKenzie \& Lutz (1989) mengartikan source credibility sebagai persepsi konsumen tentang keterbukaan dan keandalan pesan pemasaran. Kredibilitas sebuah iklan dipengaruhi oleh berbagai faktor, salah satunya adalah kredibilitas perusahaan dan kredibilitas pembawa pesan (Zernigah \& Sohail, 2012). Menurut Ghane, Shokrizadeh, Omidvar, \& Comyab (2014), kredibilitas pesan bergantung pada sejumlah faktor yang meliputi kredibilitas organisasi. Dalam penelitian ini menggunakan indikator source credibility yang dikemukakan oleh Zernigah \& Sohail (2012), dimana indikator dari source credibility tersebut adalah trustworthiness (meberikan level kredibilitas sumber informasi bagi penerimanya).

\section{Irritation}

Secara umum, setiap pesan yang menyinggung yang mungkin bertentangan dengan nilai-nilai konsumen dianggap sebagai irritation ( $\mathrm{Oh} \& \mathrm{Xu}$, 2003). Iritasi didefinisikan sebagai penggunaan taktik dalam pemasaran yang mengganggu, menyinggung, menghina, atau terlalu manipulatif dalam perspektif pemasaran (Waldt et al., 2009). Iritasi merupakan fenomena dimana konsumen cenderung menolak pesan-pesan pemasaran jika dirasa iklan tersebut terlalu mengganggu. Konsumen akan merasa jengkel dan menimbulkan sikap negatif terhadap viral marketing ketika pesan menjadi sangat manipulatif (Palka et al., 2009). Dalam penelitian ini menggunakan indikator irritation yang dikemukakan oleh Zernigah \& Sohail (2012), dimana empat indikator dari irritation tersebut adalah dangerous (memberikan pesan yang berbahaya bagi penerimanya), irritating (memberikan pesan yang menjengkelkan bagi penerimanya), annoying (memberikan pesan yang mengesalkan penerimanya) dan misleading (memberikan pesan yang menyesatkan bagi penerimanya). 


\section{Consumers' Attitude Toward Viral Marketing}

Dalam penelitian mobile viral marketing, attitude didefinisikan sebagai evaluasi keseluruhan konsumen terhadap keinginan untuk meneruskan konten viral melalui mobile device (Yang \& Zhou, 2011). Menurut Wu \& Wang (2011) attitude meliputi evaluasi yang disukai dan tidak disukai, emosi atau perasaan dan sikap perilaku. Keberhasilan kampanye mobile viral marketing pada akhirnya bergantung pada sikap dari penerima pesan, maksud dan perilaku yang mendorong penerusan pesan pemasaran ke teman dan kerabat mereka (Yang \& Zhou, 2011). Selain itu keberhasilan viral marketing message dapat dilihat dari keinginan konsumen individu untuk meneruskan pesan pemasaran kepada ratusan konsumen individu lainnya. Dalam penelitian mobile viral marketing, attitude didefinisikan sebagai evaluasi keseluruhan konsumen terhadap keinginan untuk meneruskan konten viral melalui mobile device (Yang \& Zhou, 2011).

Menurut Wu \& Wang (2011) attitude meliputi evaluasi yang disukai dan tidak disukai, emosi atau perasaan dan sikap perilaku. Keberhasilan kampanye mobile viral marketing pada akhirnya bergantung pada sikap dari penerima pesan, maksud dan perilaku yang mendorong penerusan pesan pemasaran ke teman dan kerabat mereka (Yang \& Zhou, 2011). Selain itu keberhasilan viral marketing message dapat dilihat dari keinginan konsumen individu untuk meneruskan pesan pemasaran kepada ratusan konsumen individu lainnya. Menurut Zernigah \& Sohail (2012) attitude towards viral marketing message seringkali diukur dari reaksi mereka terhadap pesan pemasaran, yang dinilai berdasarkan informativeness, entertainment, source credibility, dan irritation. Dalam penelitian ini menggunakan dua indikator consumers' attitude towards viral marketing yang dikemukakan oleh Zernigah \& Sohail (2012), yaitu consider useful marketing tool (menggunakan viral marketing message sebagai alat pemasaran yang berguna untuk menciptakan kesadaran merek) dan consider effective marketing tool (bagaimana membuat viral marketing message lebih efektif dibandingkan dengan pesan pemasaran media tradisional).

\section{Competitiveness Ability}

Menurut Rainer Feurer dan Kazem Chaharbaghi (1994) competitiveness adalah kemampuan untuk membujuk pelanggan untuk memilih penawaran mereka daripada alternatif-alternatif yang ada. CA mengacu pada kemampuan perusahaan untuk menciptakan posisi defensif terhadap pesaing mereka (Porter, 1985). Ini adalah elemen kunci dari perusahaan yang digunakan untuk mengukur dan membedakan perusahaan dari pesaingnya (Tracey et al., 1999). Helm (2000) mengemukakan bahwa target viral marketing adalah untuk memaksimalkan jangkauan. Kriteria ini sangat penting dalam mencapai competitiveness melalui viral marketing message. Reach adalah unsur keunggulan penting dari perusahaan e-bisnis (P. Evans \& Wurster, 1999). Alkharabsheh, Alsarayreh, Rumman dan Al Farajat (2011) memberikan sepuluh indikator CA yaitu information spreading competitive advantage (efektivitas penyebaran iklan), rapid implementation of new programs (kecepatan penyebaran program promosi pemasaran terkini), location based competitive advantage (keunggulan lokasi penyebaran informasi), added value (dampak interaksi virtual dan competitive pricing pada nilai tambah produk/layanan), comprehensiveness of product specification (kelengkapan informasi produk/ layanan), naturally encourage promotion (kemampuan secara natural untuk mendorong promosi produk), efficiency (menyebarkan pesan iklan produk atau layanan secara efisien), product-market fit (mempromosikan produk sesuai minat penerimanya).

\section{Business Performance}

Business performance mengacu pada sejauh mana perusahaan mencapai tujuan produksi, sumber daya manusia, pemasaran dan keuangan mereka. Business performance dapat dilihat dari segi finansial maupun yang non-finansial. Selain itu, berdasarkan rekomendasi dari beberapa periset (N. Evans, 2005; Murphy \& Callaway, 2004; Panigyrakis \& Theodoridis, 2007) untuk pengukuran kinerja, baik ukuran keuangan maupun non keuangan harus digunakan, seperti pertumbuhan, efisiensi, keuntungan, reputasi dan tujuan pribadi pemilik sebagai ukuran kinerja UKM secara keseluruhan. Penelitian ini mengadopsi pengukuran business performance melalui Ahmad, Abu Bakar, \& Ahmad (2019) yaitu sales (jumlah transaksi dan volume penjualan), customer service (kepuasan dari kualitas pelayanan) dan brand equity (keterlibatan pelanggan dan devaluasi alternatif merek lain).

\section{MODEL PENELITIAN}

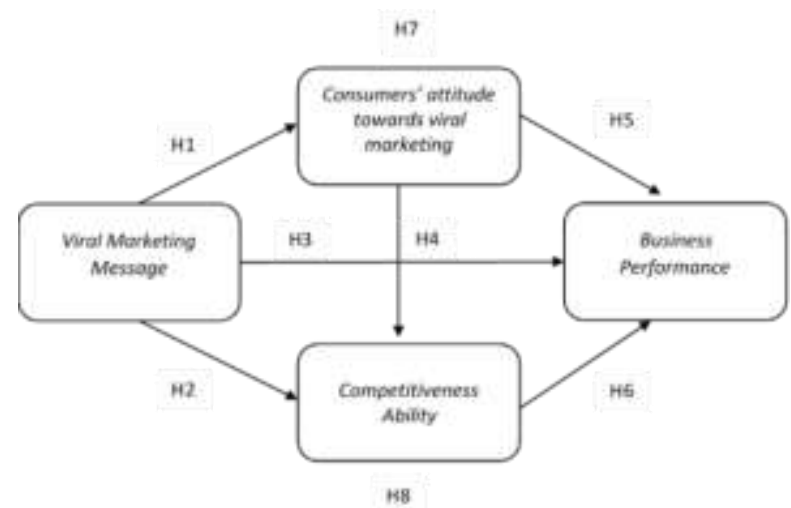

Gambar 1. Model Penelitian 


\section{HIPOTESA}

Tsang et al., (2004) menemukan bahwa VM merupakan faktor pendorong signifikan CATVM. Hal ini didukung oleh Majedul Huq (2015) dimana semua dimensi VM (entertainment, credibility, informativeness dan incentive) berpengaruh positif terhadap CATVM. Zernigah dan Sohail (2012) juga menemukan hubungan positif siginifikan antara VM (entertainment, credibility dan informativeness) dengan CATVM. Dari keseluruhan penelitian, hanya dimensi irritation yang berpengaruh negatif terhadap CATVM yang pengukurannya dalam penelitian ini diadaptasi menjadi pernyataan-pernyataan positif. Oleh karena itu dapat dihipotesiskan bahwa:

H1: Viral marketing message berpengaruh terhadap consumers' attitude towards viral marketing.

Viral marketing message dapat menyebarkan pesan apa pun ke jutaan orang dalam rentang waktu singkat dengan cara yang efektif (Haryani \& Motwani, 2015). Penelitian sebelumnya yang dilakukan oleh $D$. Tsang \& Qun (2015) pada dua perusahaan game online Eropa yaitu Jagex Games Studio dan Rovio Entertainment menunjukkan bagaimana pengaruh viral marketing message pada competitive advantage perusahaan dalam menjaga hubungan dengan end user.

H2: Viral marketing message berpengaruh terhadap competitiveness ability.

Pola pertumbuhan eksponensial yang mirip dengan penyebaran virus, viral marketing message disarankan sebagai strategi pemasaran hemat biaya yang mendorong business performance (sales) dalam waktu singkat dan memfasilitasi hubungan (engagement) antara perusahaan dan pembeli potensial (Dobele et al., 2007). Adopsi konsep mobile advertising (melalui viral marketing message) yang memiliki konsistensi pesan yang baik akan berdampak lebih besar pada business performance (sales) perusahaan dan juga memiliki frekuensi jangkauan yang baik serta memengaruhi eksposur yang berbeda ke target audiens dibandingkan beriklan melalui tradisional (seperti Iklan TV atau cetak) (Majedul Huq, 2015). Viral marketing adalah strategi yang menggunakan komunikasi peer-to-peer untuk meningkatkan kesadaran dan adopsi produk atau layanan di seluruh jaringan pembeli yang luas (Xiong \& $\mathrm{Hu}$, 2010).

H3: Viral marketing message berpengaruh terhadap business performance.

Viral Marketing mendeskripsikan strategi apa pun yang "mendorong individu untuk menyampaikan pesan pemasaran" kepada orang lain, "menciptakan potensi pertumbuhan eksponensial dalam keterpaparan atau pengaruh pesan". Seperti virus, "strategi pemasaran viral memanfaatkan perkalian cepat untuk meledakkan pesan ke ribuan bahkan jutaan orang" (Pandey et al., 2012). Mobile viral marketing adalah pendekatan yang optimal untuk memperluas jangkauan dan pengaruh pesan promosi dengan sedikit atau tanpa biaya tambahan bagi pengiklan (Pousttchi \& Wiedemann, 2007). Viral promotion yang kuat dapat menjangkau ribuan konsumen dan dapat menginspirasi mereka untuk membeli suatu merek (Bampo et al., 2008). Pengaruh consumers' attitude towards viral marketing terhadap competitiveness ability merupakan salah satu bagian dari penelitian saat ini yang bersifat eksploratif, karena peneliti mencoba menghubungkan dua variabel dari disiplin ilmu yang berbeda (consumers' attitude towards viral marketing dari online marketing communication, dan competitiveness ability dari strategic management perusahaan).

H4: Consumers' attitude towards viral marketing berpengaruh terhadap competitiveness ability.

Informativeness berdampak pada sikap konsumen terhadap iklan online karena membantu mereka dalam membuat keputusan pembelian (Tsang et al., 2004). Entertainment service menambah nilai bagi pelanggan dan meningkatkan loyalitas pelanggan sehingga mengarah pada positive consumers' attitude (Saadeghvaziri dan Hosseini, 2011). Penelitian Choi dan Rifon (2002) menemukan bahwa kredibilitas perusahaan memiliki efek positif langsung terhadap sikap terhadap iklan, merek, dan niat membeli. Penelitian sebelumnya yang dilakukan oleh Esmaeilpour dan Aram (2016) pada konsumen ponsel (Samsung, Sony, Nokia, LG dan iPhone) di kota Bushehr (Iran) menunjukkan daya tarik dan kredibilitas sumber pesan mempengaruhi consumers' attitude towards brand. Meskipun salah satu pengukuran business performance adalah brand equity (Aaker, 1996), penelitian ini berupaya untuk mengeksplorasi kaitan antara consumers' attitude dan business performance dengan cara mengikutsertakan ukuran-ukuran kinerja perusahaan lainnya seperti sales performance dan customer service.

H5: Consumers' attitude towards viral marketing berpengaruh terhadap business performance.

Molina-Azorín et al (2015) menyatakan bahwa competitive advantage merupakan suatu kemampuan yang diperoleh melalui karakteristik dan sumber daya suatu perusahaan untuk memiliki business performance yang lebih tinggi dibandingkan perusahaan lain pada industri atau pasar yang sama. Model strategis kompetitif porter menunjukkan bahwa competitive advantage meningkatkan kesehatan keuangan 
perusahaan (seperti laba, margin, dan laba atas investasi) dan kesehatan pasar (seperti pangsa pasar dan penjualan) dibandingkan dengan pesaingnya (SantosVijande et al., 2012; Weerawardena et al., 2006). Penelitian sebelumnya oleh Alkharabsheh et al. (2011) menyimpulkan bahwa promosi pariwisata secara online menggunakan viral marketing message membantu menyebarkan informasi untuk penawaran wisata di Yordania, dan jenis promosi ini membantu meningkatkan daya saing perusahaan pariwisata, seperti kredibilitas informasi untuk penawaran wisata di Yordania, dan juga menyediakan kebutuhan informasi untuk program pariwisata di Yordania yang memadai untuk keputusan pembelian oleh klien.

H6: Competitiveness ability berpengaruh terhadap business performance.

Viral marketing message berpengaruh signifikan terhadap consumers' attitude towards viral marketing yang telah dibuktikan secara empiris pada beberapa penelitian sebelumnya (De Reyck \& Degraeve, 2003; Tsang et al., 2004; Zabadi et al., 2012). Pengaruh consumers' attitude towards viral marketing terhadap competitiveness ability juga telah dibuktikan secara empiris signifikan pada beberapa penelitian terdahulu (Bampo et al., 2008; Pandey et al., 2012; Pousttchi \& Wiedemann, 2007). Beberapa penelitian ini tidak memberikan kerangka teoritis peran mediasi murni variabel consumers' attitude towards viral marketing, sehingga dalam penelitian ini pengujian peran mediasi tersebut dianalisa dengan pendekatan statistik.

H7: Consumers' attitude towards viral marketing memediasi pengaruh viral marketing terhadap competitiveness ability.

Pada beberapa penelitian sebelumnya (Bampo et al., 2008; Pandey et al., 2012; Pousttchi \& Wiedemann, 2007) telah dibuktikan secara empiris consumers' attitude towards viral marketing berpengaruh signifikan terhadap competitiveness ability. Pengaruh competitiveness ability terhadap business performance juga telah dibuktikan secara empiris signifikan pada beberapa penelitian terdahulu (Choi \& Rifon, 2002; Esmaeilpour \& Aram, 2016; Saadeghvaziri \& Hosseini, 2011; Tsang et al., 2004). Beberapa penelitian ini tidak memberikan kerangka teoritis peran mediasi murni variabel competitiveness ability, sehingga dalam penelitian ini pengujian peran mediasi tersebut dianalisa dengan pendekatan statistik.

H8: Competitiveness ability memediasi pengaruh consumers' attitude towards viral marketing terhadap business performance.

\section{METODE PENELITIAN}

Pendekatan kuantitatif kausal digunakan untuk menganalisa hubungan antara VM, CATVM, CA, dan
BP pada konteks UKM kerajinan kulit Tanggulangin, Sidoarjo. Populasi penelitian adalah seluruh konsumen UKM Kerajinan Kulit Tanggulangin, Sidoarjo (merupakan pengguna media sosial yang pernah melihat iklan pemasaran UKM). Sampel direkrut secara purposif dengan kualifikasi responden yang hanya pernah melihat iklan pemasaran dari para vendor UKM tersebut. Mayoritas konsumen merupakan generasi Z (lahir tahun 1997-2012) dan generasi milenial (lahir tahun 1981-1996) (Badan Pusat Statistik, 2019). Berdasarkan rentang usia dan generasi, survei yang dilakukan tepat karena menyebarkan viral marketing message lebih cocok untuk generasi muda yang sering menyerap informasi melalui media sosial. Selain itu, komposisi penduduk Indonesia menurut generasi mayoritas diisi oleh generasi $\mathrm{Z}$ dan milenial yaitu sekitar 144,31 juta jiwa (53.81\%) dari total penduduk Indonesia (Badan Pusat Statistik, 2019), sehingga ini memberikan peluang pasar yang besar dan potensial untuk UKM dapat fokuskan.

Dengan keterbatasan akses dan privasi data konsumen, peneliti menggunakan metode aided recall dengan memberikan poster-poster promosi online yang sering digunakan oleh para vendor UKM pada survei utama. Metode ini dilakukan kepada dua kelompok responden yaitu rekan-rekan peneliti yang memenuhi kriteria dan mahasiswa Universitas Kristen Petra tahun kedua sampai tahun keempat. Kriteria sampling secara spesifik adalah:

1. Responden pernah melihat pesan pemasaran UKM Kerajinan Kulit Tanggulangin, Sidoarjo minimal dari design experiment yang tertera di survei (foto iklan pemasaran UKM)

2. Prioritas responden adalah mahasiswa yang diikuti oleh umum (pekerja perusahaan, pebisnis, Ibu Rumah Tangga, dll) berdasarkan referensi dari yang sudah mengisi kuesioner (snowball technique)

Pengumpulan data dilakukan dengan metode mix-methods (kualitatif-kuantitatif-kualitatif) untuk meningkatkan generalisasi temuan riset. Survei utama menghasilkan 235 responden yang opininya diolah melalui analisis multivariat melalui PLS-SEM (Partial Least Square) menggunakan software SmartPLS 3.

\section{ANALISA DAN PEMBAHASAN}

\section{Profil Responden}

$70.21 \%$ responden dalam penelitian adalah perempuan sedangkan sisanya adalah laki-laki yaitu sebesar $29.79 \%$. Mayoritas responden berusia 18-24 tahun sebesar 68.09\%, 25-34 tahun sebesar 22.55\%, diikuti 35-44 tahun sebesar 7.23\%, dibawah 18 tahun hanya 1 orang dan yang diatas 44 tahun hanya 4 orang. Pekerjaan responden mayoritas adalah pelajar/ 
mahasiswa sebesar $58.72 \%$, pegawai perusahaan sebesar $22.13 \%$, dan pebisnis sebesar $11.06 \%$. Sisa pekerjaan responden lainnya yaitu ibu rumah tangga, konselor, dosen, guru, freelancer dan arsitek dengan jumlah yang sedikit.

\section{Analisa Data}

\section{Model Pengukuran PLS-SEM}

Berdasarkan uji validitas konvergen, sebuah pesan pemasaran yang viral harus berisikan informasiinformasi yang up to date, kekinian, dan yang relevan dengan preferensi dan minat dari target konsumen UKM. Lebih lanjut, pesan pemasaran harus memberikan persepsi bahwa informasi yang diberikan bersifat eksklusif, dimana informasi tersebut hanya diberikan pada anggota komunitas UKM yang terpilih saja, jadi tidak diberikan kepada semua orang. Pesan pemasaran UKM sebaiknya menghindari memberikan kesan UKM sedang menjual produknya (konten selling semata). UKM harus menghindari memberikan pesan pemasaran yang kesannya memaksakan target konsumen untuk segera melakukan pembelian. Lalu, UKM juga harus memastikan setiap pesan pemasaran mengandung unsur testimoni dari para konsumennya. Lalu, pesan pemasaran UKM sebaiknya menghindari spamming atau tidak mengunggah terlalu banyak konten secara bersamaan dan selalu muncul disemua platform media sosial yang digunakan dalam satu waktu sekaligus. UKM harus mengatur jadwal rilis konten pemasaran di setiap platform media sosial yang ada, sehingga konsumen tidak terganggu dan dapat menerima dengan baik. Selain itu, pesan pemasaran UKM sebaiknya berasal dari sumber informasi yang terpercaya, yaitu berasal dari data organisasi atau influencer yang memiliki reputasi baik dan dikenal oleh publik memiliki ketertarikan dengan produkproduk yang berasal dari kulit.

Indikator consumers' attitude toward viral marketing yang memiliki factor loading paling tinggi adalah CATVM5 (0.831) yaitu responden menyukai iklan pemasaran melalui media digital (ponsel, media sosial, email, dll). Indikator dengan factor loading paling rendah adalah CATVM1 (0.689) yaitu responden kurang menggunakan media digital (ponsel, media sosial, email, dll) untuk mengakses pesan viral mengenai sebuah merek. Indikator competitiveness ability yang memiliki factor loading paling tinggi adalah CA8 (0.845) yaitu responden menilai bahwa promosi online yang viral secara natural relevan dengan cara konsumen UKM mengakses informasi mengenai produk/jasa dan CA10 (0.845) yaitu responden menilai juga bahwa promosi online yang viral memungkinkan konsumen UKM berfokus pada produk/jasa yang menarik minat mereka. Indikator dengan factor loading paling rendah adalah CA4 yaitu responden menilai bahwa promosi online yang viral kurang meningkatkan nilai tambah produk atau layanan dari UKM. Indikator business performance yang memiliki factor loading paling tinggi adalah BP3 (0.831) yaitu responden merasa puas dengan produk atau layanan yang diberikan UKM X. Indikator dengan factor loading paling rendah adalah BP4 (0.775) yaitu responden kurang terlibat atau berpartisipasi secara intens dengan UKM. Ukuran business performance ini didukung dengan hasil riset peneliti berdasarkan data sekunder UKM Kerajinan Kulit Tanggulangin (seperti Sendy Leather, Zumma Bags, Valqo, dan Elnazbags) dari platform e-commerce.

Nilai AVE semua variabel lebih dari sama dengan 0,50 sehingga dikatakan lolos uji convergent validity. Varians pada variabel/konstruk ini dapat ditangkap lebih banyak daripada kesalahan/eror pengukurannya. Varians yang dimaksud adalah kuadrat dari simpangan baku dari jawaban responden.

\section{Discriminant Validity}

Hasil menunjukkan bahwa tidak ada item yang lebih kecil daripada nilai item variabel lainnya. Dapat dikatakan bahwa secara keseluruhan telah memenuhi syarat dan dapat dikatakan valid. Uji Fornell-Larcker criterion ini dinyatakan lolos dilihat dari nilai akar AVE atau nilai Fornell-Larcker Criterion tiap konstruk lebih besar dari korelasinya dengan konstruk lain. Hasil menunjukkan bahwa seluruh nilai akar AVE tiap variabel lebih besar daripada nilai korelasinya. Sehingga dapat dikatakan bahwa variabel penelitian ini secara keseluruhan telah memenuhi syarat discriminant validity.

\section{Uji Reliabilitas}

Nilai cronbach's alpha lebih dari sama dengan 0,70 berarti konstruk menunjukkan konsistensi dari hasil penelitiannya dan semua konstruk ini lolos uji ini. Nilai composite reliability semua konstruk lolos uji ini karena di atas 0,70. Hasil ini menunjukkan bahwa konstruk model penelitian ini sudah reliabel.

\section{Model Struktural PLS-SEM}

\section{Collinearity Statistics}

Hasil pengujian kolinearitas menunjukkan bahwa tidak terdapat multikolinearitas dalam variabelvariabel penelitian dengan nilai variance inflation factor (VIF) dibawah lima (Hair, J. F., Hult, G. T. M., Ringle, C. M., \& Sarstedt, 2014) sehingga pengujian signifikansi pengaruh struktural antar-variabel dapat dilakukan. 


\section{Akurasi dan Relevansi Prediktif Model PLS}

Dengan merujuk pada nilai koefisien determinasi (R-Square), ditemukan bahwa kombinasi pengaruh variabel VM, CATVM, dan CA secara akurat memprediksi perubahan pada BP sebesar 49.6\%. Di samping itu, pengaruh variabel VM secara akurat memprediksi perubahan pada variabel CATVM sebesar $48.8 \%$. Kombinasi pengaruh variabel VM dan CATVM secara akurat memprediksi perubahan pada CA sebear 56.9\%. Nilai Q-Square diatas nol menunjukkan bahwa masing-masing variabel independen dalam penelitian ini relevan dalam memprediksi variabel dependen.

\section{Uji Signifikansi Pengaruh}

Nilai $t$ statistics VM $\rightarrow$ CATVM adalah 17.301 (H1 diterima) yang berarti VM berpengaruh signifikan terhadap CATVM. Nilai $t$ statistics VM $\rightarrow$ CA adalah 4.101 (H2 diterima) yang berarti VM berpengaruh signifikan terhadap CA. Nilai $t$ statistics VM $\rightarrow$ BP adalah 4.175 (H3 diterima) yang berarti VM berpengaruh signifikan terhadap BP. Nilai $t$ statistics CATVM $\rightarrow$ CA adalah 8.770 (H4 diterima) yang berarti CATVM berpengaruh signifikan terhadap CA. Nilai $t$ statistics CATVM $\rightarrow$ BP adalah 2.739 (H5 diterima) yang berarti CATVM berpengaruh signifikan terhadap BP. Nilai $t$ statistics $\mathrm{CA} \rightarrow \mathrm{BP}$ adalah 2.363 (H6 diterima) yang berarti CATVM berpengaruh signifikan terhadap BP. Secara keseluruhan keenam hipotesis tersebut memiliki hubungan yang positif dan pengaruh yang signifikan dilihat dari nilai $t$ statistics yang berada diatas 1,96. Dilihat dari tstatistik, pengaruh terbesar ada pada viral marketing message terhadap consumers' attitude toward viral marketing. Untuk pengaruh yang terkecil diantara keenam hipotesis ada pada competitiveness ability terhadap business performance.

Nilai indirect effect $\mathrm{VM} \rightarrow \mathrm{CATVM} \rightarrow \mathrm{CA}$ berarti CATVM memediasi hubungan VM $\rightarrow \mathrm{CA}$ dengan nilai path coefficient yaitu 0.387 yang menandakan hubungan positif. Nilai $t$ statistics yaitu 8.043> 1,96 dan $p$-value yaitu 0,000 <0,05 (H7 diterima) berarti CATVM memediasi hubungan $\mathrm{VM} \rightarrow \mathrm{CA}$ secara signifikan namun peran mediasi ini parsial karena pengaruh langsung VM terhadap CA adalah signifikan. Nilai indirect effect $\mathrm{CATVM} \rightarrow \mathrm{CA} \rightarrow \mathrm{BP}$ berarti $\mathrm{CA}$ memediasi hubungan $\mathrm{CATVM} \rightarrow \mathrm{BP}$ dengan nilai path coefficient yaitu 0.108 yang menandakan hubungan positif. Nilai $t$ statistics yaitu 2.207> 1,96 dan $p$-value yaitu $0,027<0,05$ (H8 diterima) berarti CA memediasi hubungan CATVM $\rightarrow$ BP secara signifikan namun peran mediasi ini parsial karena pengaruh langsung CATVM terhadap BP adalah signifikan.

\section{PEMBAHASAN}

\section{Viral Marketing Message terhadap Consumers' Attitude Towards Viral Marketing}

Hasil penelitian ini menemukan bahwa secara langsung, viral marketing message berpengaruh signifikan terhadap consumers' attitude towards viral marketing UKM Kerajinan Kulit Tanggulangin, Sidoarjo. Temuan ini menunjukkan bahwa pesan pemasaran UKM yang viral dapat mendorong munculnya sikap positif dari konsumen. Semakin pesan pemasaran yang viral itu tidak irritating, maka akan semakin menghasilkan sikap konsumen yang positif terkait pesan tersebut. Temuan ini mengkonfirmasi studi sebelumnya oleh Tsang et al. (2004) yang menunjukkan adanya hubungan signifikan antara viral marketing message (entertainment, credibility, irritation dan informativeness) dan consumers' attitude towards mobile advertising. Mobile advertising mirip dengan viral marketing message pada penelitian ini karena pada mobile advertising juga terdapat unsur promosi didalamnya, hanya saja media pada penelitian Tsang et al. (2004) terbatas pada mobile, sedangkan pada penelitian ini medianya lebih beragam (mobile, desktop, PC, dll). Perbedaan penelitian Tsang et al. (2004) dengan penelitian ini terletak pada dimensi irritation yang berpengaruh negative, sedangkan pada penelitian ini semua dimensi termasuk irritation berpengaruh positif pada consumers' attitude towards viral marketing dari UKM Kerajinan Kulit Tanggulangin, Sidoarjo.

Penelitian lain yang mendukung hasil ini adalah Zabadi, Shura, \& Elsayed (2012) yang meneliti consumer attitude towards SMS advertising diantara pengguna Yordania dan menemukan bahwa persepsi konsumen terhadap nilai entertainment, credibility dan informativeness iklan SMS berpengaruh positif dengan sikap konsumen secara keseluruhan terhadap iklan SMS, tetapi sama halnya dengan Tsang et al. (2004) irritation tidak berpengaruh pada sikap konsumen dimana itu berbeda dengan hasil pada penelitian ini. Penelitian Zabadi, Shura, \& Elsayed (2012) juga fokusnya hanya melihat pengaruh sikap konsumen pada media berupa $S M S$, sedangkan penelitian ini fokusnya adalah melihat pengaruh skap konsumen pada pesan pemasaran yang viral. Selain itu, penelitian dari Majedul Huq (2015) yang meneliti tentang consumers' attitude towards mobile advertising di Bangladesh juga mendukung hasil penelitian ini. Perbedaan penelitian Majedul Huq (2015) dengan penelitian ini adalah pada jumlah dimensi yang digunakan untuk viral marketing message ada lima yaitu perceived entertainment, credibility, reward, technological familiarity, dan message frequency, 
sedangkan pada penelitian ini hanya ada empat dimensi yaitu informativeness, entertainment, irritation, dan source credibility.

\section{Viral Marketing Message terhadap Competitiveness Ability}

Hasil penelitian ini menemukan bahwa secara langsung, viral marketing message berpengaruh signifikan terhadap competitiveness ability UKM Kerajinan Kulit Tanggulangin, Sidoarjo. Temuan ini menunjukkan bahwa pesan pemasaran UKM yang viral dapat meningkatkan kemampuan bersaing dari UKM. Semakin pesan pemasaran yang viral itu tidak irritating, maka akan semakin menambah kemampuan UKM dalam bersaing. Temuan ini mengkonfirmasi studi sebelumnya dari D. Tsang \& Qun (2015) yang meneliti tentang pengaruh viral marketing message pada competitive advantage di dua perusahaan game online Eropa yaitu Jagex Games Studio dan Rovio Entertainment menunjukkan bahwa viral marketing message berperan penting dalam mempercepat interaksi antara pemasar dan pengguna di bidang media digital dimana pada akhirnya perusahaan dapat memahami dengan jelas proses penularan sosial dan menargetkan pengguna yang ada dengan baik dan secara sengaja meningkatkan kemampuan kompetitifnya. Penelitian D. Tsang \& Qun (2015) hanya fokus menyajikan tinjauan dan analisis studi viral marketing dari tahun 2001 hingga saat ini dan penerapannya di dua perusahaan game online Eropa Jagex Games Studio dan Rovio Entertainment, serta tidak membahas lebih jauh terkait hubungan antara viral marketing message dengan competitiveness ability, sedangkan penelitian ini meneliti hubungan antara keduanya.

Penelitian dari Mohr (2017) juga mendukung hipotesis penelitian ini, walaupun pada dasarnya penilaian ini berfokus untuk meneliti buzz marketing dan mengusulkan tiga proses dari buzz marketing berdasarkan literatur yang ada agar berhasil diterapkan. Namun pada penelitian ini, sekali lagi belum menunjukkan hubungan pengaruh antara perkembangan dari viral digital marketing pada competitiveness ability sebuah perusahaan. Berbeda dengan penelitian ini yang sudah menguji hubungan pengaruh antara viral marketing message dan competitiveness ability. Penelitian lainnya dari Haryani \& Motwani (2015) juga mendukung hipotesis dari penelitian ini. Penelitian (Haryani \& Motwani, 2015) meneliti pengaruh teknik pemasaran viral yang diinduksi internet pada niat beli konsumen (yang dihasilkan dari keberhasilan menjangkau pelanggan yang tepat $\rightarrow$ competitiveness ability). Teknik viral marketing pada penelitian ini memiliki tujuh faktor/dimensi yaitu immense efficacy, supportive access, professed security, message material, irrepressible, consumer enslavement, dan escalating brand, sedangkan pada penelitian ini hanya ada empat dimensi yaitu informativeness, entertainment, irritation, dan source credibility.

\section{Viral Marketing Message terhadap Business Performance}

Hasil penelitian ini menemukan bahwa secara langsung, viral marketing message berpengaruh signifikan terhadap business performance UKM Kerajinan Kulit Tanggulangin, Sidoarjo. Temuan ini menunjukkan bahwa pesan pemasaran UKM yang viral dapat meningkatkan performa bisnis dari UKM. Semakin pesan pemasaran yang viral itu tidak irritating, maka akan semakin meningkatkan performa bisnis dari UKM. Temuan ini mengkonfirmasi studi sebelumnya dari Dobele et al. (2007) yang menunjukkan adanya hubungan signifikan antara viral marketing message dan business performance. Perbedaan penelitian Dobele et al. (2007) dengan penelitian ini adalah pada jumlah dimensi yang digunakan untuk viral marketing message ada enam yaitu surprise, joy, sadness, anger, fear, dan disgust, sedangkan pada penelitian ini hanya ada empat dimensi yaitu informativeness, entertainment, irritation, dan source credibility. Perbedaan lain dari penelitian Dobele et al. (2007) dengan penelitian ini adalah pada unsur emosinya, Dobele et al. (2007) menambahkan unsur emosi dalam pesan pemasaran viral, sedangkan penelitian ini tidak.

Penelitian lain yang mendukung hipotesis ini adalah penelitian dari Wu \& Wang (2011) yang meneliti pengaruh electronic word-of-mouth (eWOM) pada kredibilitas sumber pesan terhadap sikap merek (kepercayaan merek, afeksi merek, dan niat beli). Penelitian Wu \& Wang (2011) lebih berfokus pada penggunaan salah satu dimensi dari viral marketing message saja yaitu message source credibility, sedangkan pada penelitian ini menggunakan empat dimensi dari viral marketing message yaitu informativeness, entertainment, irritation, dan source credibility.

\section{Consumers' Attitude Towards Viral Marketing terhadap Competitiveness Ability}

Hasil penelitian ini menemukan bahwa secara langsung consumers' attitude towards viral marketing berpengaruh signifikan terhadap competitiveness ability UKM Kerajinan Kulit Tanggulangin, Sidoarjo. Temuan ini menunjukkan bahwa sikap positif konsumen UKM terhadap pesan pemasaran yang viral dapat meningkatkan kemampuan bersaing dari UKM. Semakin positif sikap konsumen UKM, maka akan semakin meningkatkan kemampuan bersaing dari UKM tersebut. 
Temuan ini juga memperluas scope dari temuan empiris studi sebelumnya oleh Pousttchi \& Wiedemann (2007) dimana sikap konsumen yang positif terhadap viral marketing message akan cenderung mempengaruhi persepsi mereka terhadap efektivitas pesan promosi termasuk juga persepsi terhadap efisiensi biaya dari penggunaan digital tools yang ada (contoh: reach yang lebih besar, kemampuan personalisasi iklan berdasarkan geografis atau wilayah, sehingga konsumen memperoleh manfaat yang sesuai kebutuhan dan keinginan mereka yang sekaligus menjadi rujukan persepsi mereka terhadap competitiveness ability dari UKM). Contoh temuan empiris dari penelitian ini juga mengkonfirmasi penelitian dari Bampo et al. (2008) dimana sikap konsumen yang positif terhadap iklan pemasaran mempengaruhi persepsi mereka bahwa viral marketing tools dapat menjangkau ribuan konsumen dan pada ujungnya dapat menginspirasi mereka untuk membeli suatu merek.

\section{Consumers' Attitude Towards Viral Marketing terhadap Business Performance}

Hasil penelitian ini menemukan bahwa secara langsung consumers' attitude towards viral marketing berpengaruh signifikan terhadap business performance UKM Kerajinan Kulit Tanggulangin, Sidoarjo. Temuan ini menunjukkan bahwa sikap positif konsumen UKM terhadap pesan pemasaran yang viral dapat meningkatkan performa bisnis dari UKM. Semakin positif sikap konsumen UKM, maka akan semakin meningkatkan performa bisnis dari UKM tersebut. Temuan ini juga memperluas scope dari temuan empiris studi sebelumnya oleh Choi dan Rifon (2002) dimana sikap konsumen yang positif terhadap iklan pemasaran yang viral membawa esensi social proof yang dibutuhkan untuk mendongkrak performa bisnis terbanyak dari sisi sales dan brand equity. Temuan empiris penelitian ini juga memperluas efek dari CATVM yang positif terhadap ukuran performa yang lebih jauh (sales, customer service, dan brand equity) daripada sekedar efek CATVM terhadap attitude toward to brand (Esmaeilpour dan Aram, 2016).

\section{Competitiveness Ability terhadap Business Performance}

Hasil penelitian ini menemukan bahwa secara langsung competitiveness ability berpengaruh signifikan terhadap business performance UKM Kerajinan Kulit Tanggulangin, Sidoarjo. Temuan ini menunjukkan bahwa keunggulan bersaing yang dimiliki UKM dapat meningkatkan performa bisnis dari UKM. Semakin memiliki kemampuan bersaing yang lebih baik dari pesaingnya, maka akan semakin meningkatkan performa bisnis dari UKM tersebut. Temuan empiris dari penelitian ini mengkonfirmasi konsep dasar strategic management bahwa perusahaan yang memiliki competitive advantage (dalam penelitian ini bentuknya adalah reach yang lebih besar, kemampuan personalisasi iklan berdasarkan geografis atau wilayah, dll) tentunya akan memiliki business performance yang lebih tinggi dibandingkan perusahaan lain pada industri atau pasar yang sama (Molina-Azorín et al., 2015). Contoh temuan empiris dari penelitian ini juga mengkonfirmasi penelitian dari Ma (2000) bahwa perusahaan (dalam hal ini adalah UKM) yang memiliki competitive advantage baik dari diferensiasi (kelengkapan spesifikasi produk dalam pesan pemasaran, adanya added value dari personalisasi iklan) atau biaya (reach audience yang lebih besar) dapat menciptakan dan meningkatkan kinerja yang lebih baik.

\section{Peran mediasi Consumers' Attitude Towards Viral Marketing dalam hubungan Viral Marketing Message dan Competitiveness Ability}

Temuan ini CATVM memediasi hubungan $\mathrm{VM} \rightarrow \mathrm{CA}$ secara parsial karena pengaruh langsung VM terhadap CA adalah signifikan. Hal ini menandakan bahwa walaupun konsumen tereskpos dengan pesan pemasaran yang viral, tidak selalu disertai dengan peningkatan competitive ability dari penggunaan viral marketing tools, kecuali sikap konsumen terbentuk secara positif terlebih dahulu terkait viral marketing. Dengan demikian, persepsi konsumen yang positif terhadap pesan pemasaran UKM Kerajinan Kulit Tanggulangin, Sidoarjo harus meningkatkan terlebih dahulu sikap mereka secara afektif (emosional) terhadap viral marketing agar pada ujungnya meningkatkan persepsi mereka bahwa UKM memiliki competitiveness ability dari pemanfaatan viral marketing tools.

Hasil dari penelitian ini didukung dengan beberapa penelitian sebelumnya yang telah membuktikan secara empiris bahwa viral marketing message berpengaruh signifikan terhadap consumers' attitude towards viral marketing (De Reyck \& Degraeve, 2003; Tsang et al., 2004; Zabadi et al., 2012). Pengaruh consumers' attitude towards viral marketing terhadap competitiveness ability juga telah dibuktikan secara empiris signifikan pada beberapa penelitian terdahulu (Bampo et al., 2008; Pandey et al., 2012; Pousttchi \& Wiedemann, 2007). 


\section{Peran mediasi Competitiveness Ability dalam hubungan Consumers' Attitude Towards Viral Marketing dan Business Performance}

Temuan ini menunjukkan CA memediasi hubungan $\mathrm{CATVM} \rightarrow \mathrm{BP}$ secara parsial karena pengaruh langsung CATVM terhadap BP adalah signifikan. Hal ini menandakan bahwa walaupun sikap konsumen positif tidak selalu disertai dengan peningkatan business performance, kecuali UKM dipersepsi oleh konsumennya memiliki competitiveness ability yang terlihat signifikan (reach audience lebih besar, personalisai iklan sesuai kebutuhan dan keinginan mereka, dll). Dengan demikian, sikap konsumen yang positif terhadap pesan pemasaran viral UKM Kerajinan Kulit Tanggulangin, Sidoarjo akan mempengaruhi business performance UKM, jika sebelumnya viral marketing tools UKM dapat secara competitive menjangkau pasar dan memeberikan added value kepada konsumen (contoh: kelengkapan spesifikasi produk sebagai dasar pengambilan keputusan pembelian konsumen atau pemberdayaan teknologi informasi untuk berinteraksi dengan konsumen).

Hasil dari penelitian ini didukung dengan beberapa penelitian sebelumnya yang telah membuktikan secara empiris bahwa consumers' attitude towards viral marketing berpengaruh signifikan terhadap competitiveness ability (Bampo et al., 2008; Pandey et al., 2012; Pousttchi \& Wiedemann, 2007). Pengaruh competitiveness ability terhadap business performance juga telah dibuktikan secara empiris signifikan pada beberapa penelitian terdahulu (Choi \& Rifon, 2002; Esmaeilpour \& Aram, 2016; Saadeghvaziri \& Hosseini, 2011; Tsang et al., 2004).

\section{KESIMPULAN DAN SARAN}

\section{Kesimpulan}

Berdasarkan hasil penelitian mengenai strategi viral marketing Message, consumers' attitude towards viral marketing, competitiveness ability, dan business performance: Studi pada UKM Kerajinan Kulit Tanggulangin, Sidoarjo maka diperoleh hasil bahwa viral marketing massage berpengaruh langsung positif terhadap consumer attitudes towards viral marketing, competitiveness ability, dan business performance. Consumer attitudes towards viral marketing memiliki pengaruh positif langsung competitiveness ability, dan business performance. Selain itu, consumer attitudes towards viral marketing memediasi parsial hubungan antara viral marketing massage dan competitiveness ability, dan competitiveness ability memediasi parsial hubungan antara consumer attitudes towards viral marketing dan business performance.

\section{Saran}

\section{Saran Akademis}

Konteks penelitian ini sifatnya niche (dalam penelitian ini adalah UKM), sehingga penelitian selanjutnya diharapkan menggunakan literatur yang cakupannya spesifik. Disamping Perlu adanya penelitian empiris yang berkaitan dengan variabel-variabel spesifik seperti peer to peer recommendation (Krishnamurthy, 2001), teknik copy writing yang lebih kearah story telling (Pulizzi, 2012; Rodriguez, 2020) dibandingkan metode konvensional dalam ranah brand promotion, atau variabel lainnya seperti usergenerated content (Müller \& Christandl, 2019) yang pengaruhnya signifikan terhadap brand response (awareness, interest, desire, action).

Variabel-variabel ini berada dalam ranah literatur content marketing dan menjadi perhatian utama publik maupun pelaku bisnis saat ini karena konsumen sudah kehilangan kepercayaan terhadap brand (termasuk konten-konten yang dikelola oleh brand itu sendiri) (Nielsen, 2015).

Definisi Operasional Variabel: Item-item kuesioner perlu didefinisikan secara praktis atau kontekstual dan untuk mengurangi bias opini dari pengisian survei, penelitian selanjutnya perlu merekrut responden yang memiliki pengalaman langsung sebagai konsumen dan melihat iklan-iklan pemasaran UKM Kerajinan Kulit.

\section{Saran Praktis}

Pemilik UKM Kerajinan Kulit Tanggulangin, Sidorajo disarankan untuk lebih memperhatikan kehadiran di media digital dengan strategi dan taktik pemasaran yang tepat, agar tidak hanya scale up bisnis dari UKM saja, tetapi mampu membuat UKM juga bertahan disaat pandemi seperti saat ini. Media digital yang dapat difokuskan UKM untuk menyebarkan viral marketing message ataupun menjangkau calon konsumennya adalah Instagram, Tiktok, dan Facebook. Dari sisi teknis penggunaan media sosial khususnya Instagram, UKM dapat memperhatikan jadwal unggah konten dan memanfaatkan fitur carousel post.

Iklan pemasaran UKM dapat menggunakan storytelling, sehingga tercipta ikatan emosional antara pembaca pesan dengan isi dari pesan pemasaran UKM. Storytelling yang dimaksudkan seperti UKM sedang membangun sebuah movement melalui campaign dengan bentuk infografis ataupun video. Contoh movement yang dibangun misalnya \#Bangga Buatan Indonesia. UKM juga dapat mengeksplorasi lebih tentang buyer persona yang dimiliki dengan lebih rinci.

Terakhir dari sisi pemanfaatan e-commerce, UKM dapat lebih mengatur untuk kategori-kategori dari produk kulit yang dimiliki dengan fitur bawaan yang sudah disediakan oleh e-commerce. 


\section{DAFTAR PUSTAKA}

Aaker, D. A. (1996). Measuring brand equity across products and markets. California Management Review, 38(3).

Ahmad, S. Z., Abu Bakar, A. R., \& Ahmad, N. (2019). Social media adoption and its impact on firm performance: the case of the UAE. International Journal of Entrepreneurial Behaviour and Research, 25(1), 84-111. https://doi.org/10. 1108/IJEBR-08-2017-0299.

Ajzen, I. (1987). Attitudes, traits and actions: Dispositional prediction of behaviour in social pshychology. In Advances in Experimental Social Psychology (Vol. 20).

Alkharabsheh, K. S., Alsarayreh, M. N., Rumman, M. A., \& Al Farajat, A. H. (2011). The impact of viral marketing via Internet on promotion of tourism products in Jordan. International Research Journal of Finance and Economics, 80(May), 138-147.

Antara \& Setiawan, K. (2020). Bank Indonesia: Transaksi e-commerce agustus 2020 naik hingga mencapai 140 Juta. https://bisnis.tempo. co/read/1398066/bank-indonesia-transaksi-ecommerce-agustus-2020-naik-hingga-mencapai-140-juta?page_num=2.

Badan Pusat Statistik. (2020). Berita resmi statistik. In Badan Pusat Statistik (Issue 7/01/Th.XXIV). bps.go.id.

Bampo, M., Ewing, M. T., Mather, D. R., Stewart, D., \& Wallace, M. (2008). The effects of the social structure of digital networks on viral marketing performance. Information Systems Research, 19(3), 273-290. https://doi.org/10.1287/isre. 1070.0152 .

Bauer, H. H., Reichardt, T., Barnes, S. J., \& Marcus, M. N. (2005). Driving consumer acceptance of location-based services in mobile applications: A theoretical framework and an empirical study. Journal of Electronic Commerce Research, 6(3), 181-192.

Bella, A. (2018). Potensi besar industri kulit di Indonesia. Marketeers.Com. https://marketeers.com/ potensi-besar-industri-kulit-di-indonesia/

Bramasta, D. B. (2020). Odading mang oleh viral, begini sejarah penamaannya. Kompas. Com, $1-$ 6. https://www.kompas.com/tren/read/2020/09/ 17/183838465/odading-mang-oleh-viral-beginisejarah-penamaannya?page=all.

Castronovo, C., \& Huang, L. (2012). Social media in an alternative marketing communication model. Journal of Marketing Development and Competitiveness, 6(1), 117-134.

Chau, P. Y. K., \& Tam, K. Y. (1997). Factors affecting the adoption of open systems: An exploratory study. MIS Quarterly: Management Information Systems, 21(1), 1-20. https://doi.org/10.2307/ 249740.

Choi, S. M., \& Rifon, N. J. (2002). Antecedents and consequences of web advertising credibility. Journal of Interactive Advertising, 3(1), 12-24. https://doi.org/10.1080/15252019.2002.107220 64.

Cruz, D., \& Fill, C. (2008). Evaluating viral marketing: Isolating the key criteria. Marketing Intelligence and Planning, 26(7), 743-758. https://doi.org/ $10.1108 / 02634500810916690$

Davis, F. D. (1989). Perceived usefulness, perceived ease of use, and user acceptance of information technology. MIS Quarterly: Management Information Systems, 13(3), 319-339. https://doi.org/ $10.2307 / 249008$

De Reyck, B., \& Degraeve, Z. (2003). Broadcast scheduling for mobile advertising. Operations Research, 51(4), 509-517. https://doi.org/10. 1287/opre.51.4.509.16104

Dobele, A., Lindgreen, A., Beverland, M., Vanhamme, J., \& van Wijk, R. (2007). Why pass on viral messages? Because they connect emotionally. Business Horizons, 50(4), 291-304. https://doi. org/10.1016/j.bushor.2007.01.004

Ducoffe, R. H. (1996). Advertising value and advertising on the web. Journal of Advertising Research, 36(5), 21-21.

Esmaeilpour, M., \& Aram, F. (2016). Investigating the impact of viral message appeal and message credibility on consumer attitude toward the brand. Management and Marketing, 11(2), 470483. https://doi.org/10.1515/mmcks-2016-0010

Evans, N. (2005). Assessing the balanced scorecard as a management tool for hotels. International Journal of Contemporary Hospitality Management, 17(5), 376-390. https://doi.org/10.1108/ 09596110510604805

Evans, P., \& Wurster, T. S. (1999). Getting real about virtual commerce. Harvard Business Review, 77(6), 84-94. http://search.ebscohost.com/login. aspx?direct=true \&db=buh\&AN=2434952\&site $=$ ehost-live

Ghane, N., Shokrizadeh, H. R., Omidvar, M., \& Comyab, H. (2014). Investigating the effective factors on electronic trade by viral marketing. Management Science Letters, 4(4), 713-720. https://doi.org/10.5267/j.msl.2014.2.020

Godes, D., \& Mayzlin, D. (2004). Using online conversations to study word-of-mouth communication. Marketing Science, 23(4), 545-560. https://doi.org/10.1287/mksc.1040.0071

Goldsmith, R. E., \& Horowitz, D. (2006). Measuring motivations for online opinion seeking. Journal 
of Interactive Advertising, 6(2), 2-14. https://doi.org/10.1080/15252019.2006.107221 14

Hair, J. F., Hult, G. T. M., Ringle, C. M., \& Sarstedt, M. (2014). Multivariate data analysis, 7th edition. USA: Prentice Hall: Pearson Education International.

Haryani, S., \& Motwani, B. (2015). Discriminant model for online viral marketing influencing consumers behavioural intention. Pacific Science Review B: Humanities and Social Sciences, 1(1), 49-56. https://doi.org/10.1016/ j.psrb.2015.12.002

Helm, S. (2000). Viral marketing - Establishing customer relationships by "word-of-mouse." Electronic Markets, 10(3), 158-161. https://doi. org/10.1080/10196780050177053

Icek, A. (1991). The theory of planned behavior organizational behavior and human decision processes. Organizational Behavior and Human Decision Processes, 50(2), 179-211.

Jensen, M. B. (2008). Online marketing communication potential: Priorities in Danish firms and advertising agencies. European Journal of Marketing, 42(3-4), 502-525. https://doi.org/10. $1108 / 03090560810853039$

Kaplan, A. M., \& Haenlein, M. (2011). Two hearts in three-quarter time: How to waltz the social media/viral marketing dance. Business Horizons, 54(3), 253-263. https://doi.org/10.1016/ j.bushor.2011.01.006

Krishnamurthy, S. (2001). Understanding online message dissemination: An analysis of Sendthis-story-to-your-friend data. First Monday, 6. https://doi.org/https://doi.org/10.5210/fm.v6i5.8 56

Lee, S. F., Tsai, Y. C., \& Jih, W. J. (2006). An empirical examination of customer perceptions of mobile advertising. Information Resources Management Journal, 19(4), 39-55. https://doi. org/10.4018/irmj.2006100103

Ma, H. (2000). Competitive advantage and firm performance. Competitiveness Review, 10(2), 15-32. https://doi.org/10.1108/eb046396

MacKenzie, S. B., \& Lutz, R. J. (1989). An empirical examination of the structural antecedents of attitude toward the ad in an advertising pretesting context. Journal of Marketing, 53(2), 48-65. https://doi.org/10.2307/1251413

Majedul Huq, S. (2015). Customer's attitude towards mobile advertising in Bangladesh. International Journal of Business and Economics Research, 4(6), 281-292. https://doi.org/10.11648/j.ijber. 20150406.13

Meyliana, M., E. W., H. A., \& Santoso, S. W. (2015). The influence of customers communication behaviour in the implementation of 21cineplex viral marketing using the social networking site Facebook. CommIT (Communication and Information Technology) Journal, 9(1), 11-18. https://doi.org/10.21512/commit.v9i1.863

Mohr, I. (2017). Managing buzz marketing in the digital age. Journal of Marketing Development and Competitiveness, 11(2), 10-16.

Molina-Azorín, J. F., Tarí, J. J., Pereira-Moliner, J., López-Gamero, M. D., \& Pertusa-Ortega, E. M. (2015). The effects of quality and environmental management on competitive advantage: A mixed methods study in the hotel industry. Tourism Management, 50, 41-54. https://doi. org/10.1016/j.tourman.2015.01.008

Müller, J., \& Christandl, F. (2019). Content is king But who is the king of kings? The effect of content marketing, sponsored content \& usergenerated content on brand responses. Computers in Human Behavior, 96(February), 46-55. https://doi.org/10.1016/j.chb.2019.02.006

Murphy, G. B., \& Callaway, S. K. (2004). Doing well and happy about it? Explaining variance in entrepreneurs' stated satisfaction with performance. New England Journal of Entrepreneurship, 7(2), 15-26. https://doi.org/10.1108/neje07-02-2004-b003

Nielsen. (2015). Global trust in advertising. The Nielsen Company, September, 1-22.

Oh, L., \& Xu, H. (2003). Effects of multimedia on mobile consumer behavior: An empirical study of location-aware advertising. ICiS 2003 Proceedings, 56.

Palka, W., Pousttchi, K., \& Wiedemann, D. G. (2009). Mobile word-of-mouth - A grounded theory of mobile viral marketing. Journal of Information Technology, 24(2), 172-185. https://doi.org/10. 1057/jit.2008.37

Pandey, J., Sunaina, R., \& Sundar, A. (2012). A study on factors affecting the exposure to viral marketing messages. International Journal of Management \& Business Studies, 2(1), 105111.

Panigyrakis, G. G., \& Theodoridis, P. K. (2007). Market orientation and performance: An empirical investigation in the retail industry in Greece. Journal of Retailing and Consumer Services, 14(2), 137-149. https://doi.org/10. 1016/j.jretconser.2006.05.003

Park, D. H., Lee, J., \& Han, I. (2007). The effect of online consumer reviews on consumer purchasing intention: The moderating role of involvement. International Journal of Electronic Commerce, 11(4), 125-148. https://doi.org/10.2753/JEC $1086-4415110405$ 
Pavlou, P. a, \& Fygenson, M. (2006). Understanding and predicting electronic commerce adoption: An extension of the theory of the planned behavior. Mis Quarterly, 30(1), 115-143.

Porter, M. E. (1985). Competitive advantage: creating and sustaining superior performance. Free Press.

Pousttchi, K., \& Wiedemann, D. G. (2007). Success factors in mobile viral marketing: A multi-case study approach. Conference Proceedings - 6th International Conference on the Management of Mobile Business, ICMB 2007, May. https://doi.org/10.1109/ICMB.2007.61

Pulizzi, J. (2012). The rise of storytelling as the new marketing. Publishing Research Quarterly, 28(2), 116-123. https://doi.org/10.1007/s12109012-9264-5

Putri, N. K., \& Ernawaty, E. (2019). Viral marketing content for Universal Health Coverage campaign in Indonesia. International Journal of Pharmaceutical and Healthcare Marketing, 14(1), 21-36. https://doi.org/10.1108/IJPHM07-2017-0041

Rainer Feurer, \& Kazem Chaharbaghi. (1994). Defining competitiveness: a holistic approach. Management Decision, 32(2), 49-58. http://repository.binus.ac.id/20092/content/F0542/F054214618.pdf

Rodriguez, M. (2020). Brand storytelling: Put customers at the heart of your brand story. Kogan Page Publishers.

Saadeghvaziri, F., \& Hosseini, H. K. (2011). Mobile advertising: An investigation of factors creating positive attitude in Iranian customers. African Journal of Business Management, 5(2), 394 404. https://doi.org/10.5897/AJBM10.431

Santos-Vijande, M. L., López-Sánchez, J. Á., \& Trespalacios, J. A. (2012). How organizational learning affects a firm's flexibility, competitive strategy, and performance. Journal of Business Research, 65(8), 1079-1089. https://doi.org/10. 1016/j.jbusres.2011.09.002

Shen, X., \& Chen, H. (2008). An empirical study of what drives consumers to use mobile advertising in China. Proceedings - 3rd International Conference on Grid and Pervasive Computing Symposia/Workshops, GPC 2008, 158-163. https://doi.org/10.1109/GPC.WORKSHOPS.20 08.37

Tornatzky, L. G., Fleischer, M., \& Chakrabarti, A. K. (1990). Processes of technological innovation. Lexington books.

Tracey, M., Vonderembse, M. A., \& Lim, J. S. (1999). Manufacturing technology and strategy formulation: Keys to enhancing competitiveness and improving performance. Journal of Operations Management, 17(4), 411-428. https://doi.org/ 10.1016/S0272-6963(98)00045-X

Travel, V. F. (2020). 5 fakta seputar odading Mang Oleh, mulai dari celetukan kini jadi makanan viral. https://kumparan.com/viral-food-travel/5fakta-seputar-odading-mang-oleh-mulai-dariceletukan-kini-jadi-makanan-viral$1 \mathrm{uF} 8 \mathrm{mKaAvWs}$ /full

Tsang, D., \& Qun, R. (2015). Viral marketing and the new competitive advantage. Journal of Organisational Studies and Innovation, 2(1), 41-54.

Tsang, M. M., Ho, S. C., \& Liang, T. P. (2004). Consumer attitudes toward mobile advertising: An empirical study. International Journal of Electronic Commerce, 8(3), 65-78. https://doi. org/10.1080/10864415.2004.11044301

Van der Lans, R., Van Bruggen, G., Eliashberg, J., \& Wierenga, B. (2010). A viral branching model for predicting the spread of electronic word of mouth. Marketing Science, 29(2), 348-365. https://doi.org/10.1287/mksc.1090.0520

Waldt, D. L. R. Van Der, Rebello, T. M., \& Brown, W. J. (2009). Attitudes of young consumers towards SMS advertising. African Journal of Business Management, 3(9), 444-452. https://doi.org/10. 5897/AJBM09.161

Weerawardena, J., O’Cass, A., \& Julian, C. (2006). Does industry matter? Examining the role of industry structure and organizational learning in innovation and brand performance. Journal of Business Research, 59(1), 37-45. https://doi. org/10.1016/j.jbusres.2005.02.004

Wiedemann, D. G. (2007). Exploring the concept of mobile viral marketing through case study research. Lecture Notes in Informatics (LNI), Proceedings - Series of the Gesellschaft Fur Informatik (GI), P-104, 49-60.

Wu, P. C. s., \& Wang, Y. C. (2011). The influences of electronic word-of-mouth message appeal and message source credibility on brand attitude. Asia Pacific Journal of Marketing and Logistics, 23(4), 448-472. https://doi.org/10.1108/13555 851111165020.

Xiong, L., \& Hu, C. (2010). Harness the power of viral marketing in hotel industry: A network discount strategy. Journal of Hospitality and Tourism Technology, 1(3), 234-244. https://doi.org/10. 1108/17579881011078368.

Yang, H., \& Zhou, L. (2011). Extending TPB and TAM to mobile viral marketing: An exploratory study on American young consumers mobile viral marketing attitude, intent and behavior. Journal of Targeting, Measurement and 
Analysis for Marketing, 19(2), 85-98. https://doi. org/10.1057/jt.2011.11.

Zabadi, A. M. A., Shura, M., \& Elsayed, E. A. (2012). Consumer attitudes toward SMS advertising among Jordanian users. International Journal of Marketing Studies, 4(1), 77. https://doi.org/10. 5539/ijms.v4n1p77.
Zernigah, K. I., \& Sohail, K. (2012). Consumers' attitude towards viral marketing in Pakistan. 7(4), 645-662.

Zhang, E. M. (2010). Understanding the acceptance of mobile SMS advertising among young chinese consumers. Psychology \& Marketing, 30(6), 461-469. https://doi.org/10.1002/mar. 